\title{
PEMANFAATAN INFORMASI PENYULUHAN PERTANIAN (CYBER EXTENSION) BAGI PENYULUH PERTANIAN DI PROVINSI PAPUA DAN PAPUA BARAT
}

(Studi Kasus Pada Pelatihan Dasar Fungsional Penyuluh Pertanian Terampil THL-TBPP)

\section{Utilization of Agricultural Extension (Cyber Extension) for Agricultural Extension Worker in of Papua and West Papua Provinces}

(Case Study on Functional Basic Training Skilled Agricultural Extension of THL-TBPP)

\author{
Rezky Yulianti \\ Balai Besar Pelatihan Pertanian Batangkaluku \\ e-mail: reqqulipelanduk@yahoo.com
}

Received: 21 Oktober 2020; Accepted: 30 November 2020; Published: 25 Desember 2020

\begin{abstract}
ABSTRAK
Penelitian ini bertujuan untuk mengetahui karakteristik penyuluh pertanian dan pemanfaatan informasi penyuluhan pertanian yaitu Cyber Extension pada peserta Pelatihan Dasar Fungsional Penyuluh Pertanian Terampil THL-TBPP di Provinsi Papua dan Papua Barat. Pelaksanaan penelitian dilakukan pada Bulan Oktober 2018 di Balai Besar Pelatihan Pertanian Batangkaluku, Kabupaten Gowa, Provinsi Sulawesi Selatan. Responden dalam penelitian ini adalah semua peserta Pelatihan Dasar Fungsional Penyuluh Pertanian Terampil THL-TBPP Provinsi Papua dan Papua Barat sebanyak 29 orang. Teknik pengumpulan data yang digunakan dalam penelitian ini menggunakan instrumen berupa kuisioner, kemudian dilanjutkan dengan wawancara dan observasi langsung. Selanjutnya data dianalisis dan ditampilkan melalui tabel distribusi frekuensi Hasil penelitian menunjukkan bahwa responden memiliki karakteristik yang beragam, selain itu dalam memanfaatkan informasi penyuluhan juga termasuk kategori rendah.
\end{abstract}

Kata kunci: Karakteristik, penyuluh pertanian, informasi penyuluhan, cyber extension

\begin{abstract}
This study aims to determine the characteristics of agricultural extension worker and the use of agricultural extension information, namely cyber extension for participants of Functional Basic Training Skilled Agricultural Extension of THL-TBPP in Papua and West Papua Provinces. This study was carried out in October 2018 at The National Agricultural Training Center of Batangkaluku, Gowa Regency, South Sulawesi Province. Respondents in this study were all 29 participants of Functional Basic Training Skilled Agricultural Extension of THL-TBPP in Papua and West Papua Provinces. Data collection technique used in this study used an instrument in the form of questionnaire, then continued with interviews and direct observation.Furthermore, data were analyzed and displayed through a distribution table of frequency. The results showed that respondents had various characteristics, in addition to utilizing extension information it was also in the low category.
\end{abstract}

Keywords: Characteristics, agricultural extension worker, extension information, cyber extension

Diterbitkan Oleh, 


\section{PENDAHULUAN}

Saat ini kalangan masyarakat baik yang ada di daerah perkotaan maupun yang ada di pedesaan sangat cepat memperoleh informasi baik yang ada di media massa maupun media sosial. Penyebaran informasi yang positif merupakan salah satu kunci suksesnya pembangunan pertanian yang didukung oleh kapasitas penyuluh pertanian.

Pembangunan pertanian yang

berkelanjutan terletak pada upaya dan kapasitas yang dimiliki oleh penyuluh pertanian. Peran penting yang dimiliki oleh penyuluh pertanian sebagai ujung tombak pembangunan pertanian dituntut memiliki pengetahuan, informasi yang memadai untuk petani, dan kemampuan untuk akses dan tanggap terhadap perkembangan teknologi informasi.

Salah satu teknologi informasi dibidang pertanian yang dikembangkan saat ini adalah program Cyber Extension. Teknologi informasi tersebut diharapkan dapat mempercepat penyebaran informasi penyuluhan pertanian agar efektif dan efisien serta memenuhi 4 tepat yaitu tepat waktu, tepat tempat, tepat sasaran dan tepat kebutuhan. Penyebaran informasi penyuluhan pertanian melalui sistem jaringan yang terkoneksi dengan internet, hal ini dimaksudkan agar informasi pertanian yang dibutuhkan oleh pelaku utama maupun pelaku usaha dan masyarakat pertanian pada umumnya dapat setiap saat diperoleh dan dipilih sesuai kebutuhan spesifik lokasi. Sistem jaringan yang terkoneksi ini diharapkan mampu meningkatkan produktivitas kerja penyuluh dan penyuluhan, dalam pelayanan yang efisien, cepat, mudah, akurat, murah, aman, terpadu dan akuntabel.

Cyber Extension merupakan sistem informasi penyuluhan pertanian melalui media internet yang dibangun untuk mendukung penyediaan materi penyuluhan dan informasi pertanian bagi penyuluh dalam memfasilitasi proses pembelajaran agribisnis pelaku utama dan pelaku usaha. Cyber Extension dapat dimanfaatkan untuk kegiatan pelayanan data dan informasi penyuluhan, khususnya membantu memperlancar dan mempermudah fasilitasi kepada pelaku penyuluhan terutama para penyuluh pertanian, baik penyuluh pertanian PNS, swasta maupun swadaya.
Sistem informasi penyuluhan pertanian sebagai sumber pengetahuan dapat membantu penyuluh dalam menyusun materi penyuluhan dan juga dapat mengubah pola pikir, perilaku dan kesejahteraan petani. Merujuk pada penelitian Wijaya (2019) bahwa pemanfaatan sistem informasi dan teknologi melalui Cyber Extension pada hakekatnya akan menunjang pembangunan pertanian jika dimanfaatkan sebagaimana mestinya. Pemanfaatan Cyber Extension di berbagai daerah berbeda-beda tergantung kemampuan penyuluh pertanian dalam mengakses infomasi yang tersedia. Umumnya keefektifan media komunikasi ini terlihat di kota besar, termasuk di Kabupaten Bogor sedangkan di berbagai pelosok pedesaan, media ini kurang dimanfaatkan. Pemanfaatan media ini tergantung pada karakteristik petani, karakteristik penyuluh dan jenis teknologi ini sendiri sebagai inovasi.

Begitu pula dengan penelitian Permatasari (2012) bahwa penyuluh pertanian perlu diberikan penyuluhan dan pelatihan mengenai penggunaan media komunikasi Cyber Extension, manfaat menggunakan media komunikasi tersebut dalam mencari informasi tentang teknologi pertanian. Cyber Extension merupakan mekanisme yang dapat dioptimalkan dengan dukungan program peningkatan kapasitas penyuluh sebagai pendamping dalam pemanfaatan Cyber Extension.

Indonesia yang memiliki wilayah geografis yang luas terdiri dari 34 Provinsi yang tersebar di berbagai wilayah kepulauan. Kondisi geografis yang luas tersebut dengan jangkauan internet yang berbeda-beda menyebabkan beberapa wilayah yang memang masih sulit untuk dijangkau internet memiliki kesulitan dalam penyebaran informasi penyuluhan pertanian. Salah satu wilayah yang sulit untuk dijangkau internet adalah Papua dan Papua Barat. Selain kesulitan jangkauan internet, hal yang menjadi kendala adalah sumberdaya manusia yang ada di wilayah tersebut. Kenyataan yang ada saat ini banyak informasi penyuluh pertanian yang tidak sampai kepada mereka, sehingga masyarakat tidak mengetahui jika ada perkembangan informasi yang telah dikeluarkan oleh pemerintah. Keberadaan informasi penyuluhan pertanian cyber extension menjadi bernilai jika termanfaatkan oleh penyuluh, sehingga keberadaannya penting untuk diteliti

Diterbitkan Oleh, 
sehingga dapat diketahui sejauh mana pemanfaatan media ini sebagai media informasi oleh penyuluh pertanian sebagai agen pembangunan.

Dari permasalahan diatas, dilakukan penelitian dengan judul "Pemanfaatan Informasi Penyuluhan Pertanian (Cyber Extension) Bagi Penyuluh Pertanian di Provinsi Papua dan Papua Barat (Studi Kasus Pada Pelatihan Dasar Fungsional Penyuluh Pertanian Terampil THLTBPP)".

Tujuan penelitian ini adalah mengetahui karakteristik penyuluh pertanian dan pemanfaatan informasi penyuluhan pertanian yaitu Cyber Extension pada peserta Pelatihan Dasar Fungsional Penyuluh Pertanian Terampil THL-TBPP di Provinsi Papua dan Papua Barat.

\section{METODE PENELITIAN}

Pelaksanaan penelitian dilakukan pada Bulan Oktober 2018 di Balai Besar Pelatihan Pertanian Batangkaluku, Kabupaten Gowa, Provinsi Sulawesi Selatan. Responden dalam penelitian ini adalah semua peserta Pelatihan Dasar Fungsional Penyuluh Pertanian Terampil THLTBPP Provinsi Papua dan Papua Barat sebanyak 29 orang. Penelitian ini merupakan penelitian deskriptif kuantitatif, digunakan untuk mendeskripsikan atau menggambarkan data yang telah terkumpul sebagaimana adanya. Teknik pengumpulan data yang digunakan dalam penelitian ini menggunakan instrumen yang berupa kuisioner. Kuesioner (angket) merupakan teknik pengumpulan data yang dilakukan dengan cara memberi seperangkat pertanyaan atau pernyataan tertulis kepada responden untuk dijawabnya, kemudian dilanjutkan dengan wawancara kepada peserta dan observasi langsung. Selanjutnya data dianalisis dan ditampilkan melalui tabel distribusi frekuensi. Pada penelitian ini menggunakan beberapa pengamatan sebagai berikut:

1. Karakteristik penyuluh pertanian yang diukur dengan asal Kabupaten, umur, tingkat pendidikan dan lama bekerja sebagai penyuluh.

2. Pemanfaatan informasi penyuluhan pertanian yang diukur dengan indikator kemampuan dalam mengoperasikan komputer/laptop, ketersediaan sarana dalam bentuk jaringan internet dan komputer/laptop/Hp android, kemampuan dalam akses internet dalam menyusun materi penyuluhan, dan kemampuan dalam akses informasi penyuluhan pertanian (akses Cyber Extension). Ketiga indikator tersebut menggunakan skala ordinal yang digolongkan dalam kategori tinggi,sedang dan rendah.

\section{HASIL DAN PEMBAHASAN}

\section{Karakteristik Penyuluh}

Karakteristik penyuluh dapat menjadi pembeda dan ciri yang khas antara penyuluh yang satu dengan penyuluh yang lainnya. Karakteristik penyuluh yang diamati meliputi asal Kabupaten, gender, umur, tingkat pendidikan dan lama kerja sebagai penyuluh terlihat pada Tabel 1 .

\section{Kabupaten}

Berdasarkan data yang telah diolah, responden berasal dari dua Kabupaten yaitu sebanyak 55,2\% responden berasal dari Papua dan $44,8 \%$ berasal dari Papua Barat. Melihat kondisi asal peserta, yang lokasi wilayahnya sulit untuk dijangkau internet sehingga mereka mengalami kesulitan dalam mengakses internet.

\section{Umur}

Sebanyak $48,3 \%$ penyuluh pertanian berjenis kelamin laki-laki dan $51,7 \%$ perempuan. Hal ini menunjukkan bahwa pekerjaan penyuluh di lapang ternyata tidak lagi didominasi oleh laki-laki, perempuan juga berkontribusi dalam pembangunan pertanian. Hal ini tertuang dengan diterbitkannya Inpres Nomor 9 tahun 2000 yang mengamanatkan pengarusutamaan gender (PUG) atau gender mainstreming dalam pembangunan pertanian adalah strategi untuk mewujudkan kesetaraan dan keadilan gender dalam pembangunan, dimana aspek gender harus terintegrasi dalam perumusan kebijakan program dan kegiatan sejak perencanaan hingga evaluasi. Peningkatan peranan perempuan dalam pembangunan mendapat perhatian yang besar dari pemerintah, dimana upaya peningkatan status dan kedudukan perempuan dalam semua aspek pembangunan status dan kondisi perempuan tertuang sebagai isu lintas bidang pembangunan. 
Tabel 1. Karakteristik penyuluh

\begin{tabular}{|c|c|c|}
\hline Karakteristik Penyuluh & Frekuensi (orang) & Persentase $(\%)$ \\
\hline \multicolumn{3}{|l|}{ Kabupaten } \\
\hline Papua & 16 & 55,2 \\
\hline Papua Barat & 13 & 44,8 \\
\hline \multicolumn{3}{|l|}{ Gender } \\
\hline Laki-Laki & 14 & 48,3 \\
\hline Perempuan & 15 & 51,7 \\
\hline \multicolumn{3}{|l|}{ Umur } \\
\hline 25 - 30 Tahun & 7 & 24,1 \\
\hline 31 - 35 Tahun & 19 & 65,6 \\
\hline 36 - 40 Tahun & 3 & 10,3 \\
\hline \multicolumn{3}{|l|}{ Tingkat Pendidikan } \\
\hline SLTA & 23 & 79,3 \\
\hline DIII & 6 & 20,7 \\
\hline $\mathrm{S} 1$ & 0 & 0 \\
\hline \multicolumn{3}{|c|}{ Lama Kerja sebagai Penyuluh } \\
\hline $1-5$ Tahun & 0 & 0 \\
\hline $6-10$ Tahun & 26 & 89,7 \\
\hline $11-15$ Tahun & 3 & 10,3 \\
\hline
\end{tabular}

Dari data yang disajikan pada tabel 1, mayoritas responden berada dalam kisaran umur 31-35 tahun sebanyak 65,6\%. Usia tersebut masih tergolong usia yang produktif untuk bisa berkontribusi dalam kegiatan pembangunan pertanian terutama dalam memberikan informasi penyuluhan pertanian bagi petani. Hal ini sejalan dengan hasil penelitian yang dilakukan oleh Bahua et al. (2013) bahwa umur penyuluh sangat berpengaruh pada kinerja. Penyuluh yang berumur produktif biasanya cenderung memiliki fisik yang lebih kuat dan lebih kreatif dibanding dengan penyuluh yang sudah tidak produktif, tapi memiliki sifat cepat bosan pada pekerjaan yang dijalaninya, seperti hasil penelitian yang dilakukan Wuriani et al. (2014) bahwa pekerja dengan umur yang masih muda memiliki kelemahan cepat bosan, tanggungjawab yang rendah, sering tidak masuk dan memiliki keinginan yang tinggi untuk pindahpindah kerja. Diluar hal tersebut, tidak semuanya penyuluh yang berumur muda memiliki kemampuan dalam mengakses informasi pertanian, hal itu juga perlu didukung oleh kemauan untuk bisa belajar dalam mengakses informasi pertanian terutama yang berbasis internet.

\section{Tingkat pendidikan}

Sebagian besar penyuluh yang menjadi peserta Pelatihan Dasar Fungsional Penyuluh Pertanian Terampil THL-TBPP telah mengenyam pendidikan sampai tingkat SLTA dan DIII. Sebanyak 79,3\% mengenyam pendidikan sampai tingkat SLTA dan 20,7\% mengenyam pendidikan sampai tingkat DIII. Masih adanya lulusan SLTA karena di bawah tahun 90an penyuluh lulusan ini masih bisa bergabung untuk menjadi penyuluh pertanian. Menurut Okwu dan Umoru (2009), tingkat pendidikan seseorang akan menentukan kebutuhannya terhadap akses inovasi teknologi.

\section{Lama kerja sebagai penyuluh}

Dari data yang telah diolah, diketahui bahwa sebanyak $89,7 \%$, responden memiliki masa kerja yang cukup lama yaitu kisaran 6-10 tahun. Hal ini dikarenakan responden merupakan penyuluh pertanian yang berasal dari tenaga harian 
lepas yang sudah mengabdi cukup lama dilapangan yang terangkat menjadi PNS dan mengikuti pelatihan dasar penyuluh pertanian.

\section{Pemanfaatan Informasi Penyuluhan Pertanian}

Berdasarkan Tabel 2, kemampuan responden dalam mengoperasikan komputer/laptop sebanyak $62,1 \%$ pada kategori rendah. Hal ini disebabkan penyuluh tidak memiliki komputer/laptop sehingga mereka tidak memliki kemampuan untuk mengasah dalam melatih keterampilan mengoperasikan komputer tersebut, dampaknya adalah keterbatasan dalam memperoleh informasi pertanian. Hal ini sejalan dengan penelitian yang dilakukan oleh Umanailo (2016), bahwa pokok permasalahan yang timbul sehingga terjadi keterbatasan pemanfaatan teknologi informasi salah satunya adalah keterbatasan ketersediaan sarana dan prasarana.

Tabel 2. Indikator pemanfaatan informasi penyuluhan pertanian

\begin{tabular}{lcccccc}
\hline \multirow{2}{*}{ Indikator } & \multicolumn{3}{c}{ Kategori (Orang) } & \multicolumn{3}{c}{ Kategori (\%) } \\
\cline { 2 - 7 } & Rendah & Sedang & Tinggi & Rendah & Sedang & Tinggi \\
\hline $\begin{array}{l}\text { Kemampuan dalam } \\
\text { mengoperasikan } \\
\text { komputer/Laptop }\end{array}$ & 18 & 6 & 5 & 62,1 & 20,7 & 17,2 \\
$\begin{array}{l}\text { Ketersediaan sarana dan } \\
\text { prasarana dalam bentuk } \\
\text { jaringan internet dan } \\
\text { komputer/laptop/hp android }\end{array}$ & 15 & 9 & 5 & 51,7 & 31,1 & 17,2 \\
$\begin{array}{l}\text { Kemampuan akses internet } \\
\text { dalam menyusun materi } \\
\text { penyuluhan }\end{array}$ & 15 & 7 & 7 & 51,7 & 24,1 & 24,1 \\
$\begin{array}{l}\text { Kemampuan akses informasi } \\
\text { penyuluhan pertanian (Cyber }\end{array}$ & 28 & 0 & 1 & 96,6 & 0 & 3,4 \\
Extension) & & & & & & \\
\hline
\end{tabular}

Dalam hal ketersediaan sarana dan prasarana dalam bentuk jaringan internet dan komputer/laptop/hp android, termasuk kategori rendah yaitu $51,7 \%$. Kategori rendah disebabkan beberapa wilayah yang jaringan koneksi internetnya kurang baik dan tidak mendukung dalam akses informasi penyuluhan pertanian. Selain jaringan internet yang kurang baik, yang menjadi kendala juga keterbatasan laptop/komputer sehingga mereka hanya mengandalkan hp android. Berdasarkan hasil penelitian Wijaya (2019), ketersediaan sarana internet yang rendah disebabkan karena minimnya fasilitas modem atau wifi, jika ada terkadang sinyalnya kurang mendukung untuk akses internet. Tersedianya akses internet menjadi hal penting untuk membantu kinerja penyuluh.
Kemampuan akses internet dalam menyusun materi penyuluhan sebesar $51,7 \%$ yang termasuk kategori rendah. Dari hasil perolehan data dilapangan, rendahnya kemampuan dalam akses internet adalah karena keterbatasan jaringan, keterbatasan sarana prasarana berupa laptop dan komputer serta keterbatasan sumberdaya manusia yang masih belum mahir dalam mengoperasikan komputer. Kemampuan dalam akses internet sangatlah penting terutama mendukung tugas pokok dan fungsi penyuluh pertanian dalam menyampaikan informasi dan teknologi terkini. Veronice (2013) menyatakan bahwa salah satu unsur penting yang harus dimiliki oleh penyuluh pertanian adalah kemampuan dalam mengakses teknologi informasi dan komunikasi di bidang pertanian untuk mendukung perannya dalam memberikan layanan informasi sesuai dengan

Diterbitkan Oleh, 
kebutuhan petani dan mengikuti perkembangan ilmu pengetahuan teknologi dan komunikasi yang berlangsung cepat. Untuk menunjang pencapaian tersebut, penyuluh pertanian dapat mencari dan mengakses sumber-sumber informasi dari media online sehingga pada nantinya petani mampu meningkatkan daya saing usaha taninya.

Sebagai penyuluh pertanian, sudah menjadi kewajiban untuk mengetahui salah satu informasi penyuluhan pertanian yaitu Cyber Extension. Dari hasil analisis data diperoleh, kemampuan responden akses informasi penyuluhan pertanian (Cyber Extension) termasuk kategori rendah yaitu $96,6 \%$ yang artinya dari 29 sampel, hanya 1 orang yang mengetahui aplikasi tersebut, sisanya 28 orang sama sekali tidak mengetahui. Hal ini disebabkan karena mereka sama sekali tidak pernah mendengar dan tersosialisasi mengenai Cyber Extension.. Ketidakmampuan penyuluh dalam akses internet menjadi hambatan tersendiri dalam kelancaran akses Cyber Extension. Mulyandari (2011) mengemukakan bahwa peningkatan kapasitas penyuluh dalam mengakses dan menerapkan teknologi informasi merupakan kunci untuk mengembangkan Teknologi Informasi dan Komunikasi (TIK) yang efektif dalam lingkup pertanian, termasuk pengembangan teknologi Cyber Extension.

\section{KESIMPULAN}

Karakteristik penyuluh pada penelitian ini adalah berasal dari dua Provinsi yaitu Papua dan Papua Barat, dengan perbandingan gender yang hampir sama antara perempuan dan laki-laki. Sebagian besar penyuluh berada pada usia produktif yaitu 31-35 tahun, dengan tingkat pendidikan mayoritas SLTA. Berdasarkan lama bekerja sebagai penyuluh, rata-rata sudah menjadi penyuluh 6-10 tahun.

Pemanfaatan informasi penyuluhan pertanian yaitu cyber extension pada peserta Pelatihan Dasar Fungsional Penyuluh Pertanian Terampil THL-TBPP di Provinsi Papua dan Papua Barat termasuk kategori rendah. Hal ini dapat dilihat dari beberapa indikator yang kesemuanya masuk kategori rendah, diantaranya kemampuan dalam mengoperasikan komputer/Laptop, ketersediaan sarana dan prasarana dalam bentuk jaringan internet dan komputer/laptop/hp android, kemampuan akses internet dalam menyusun materi penyuluhan, kemampuan akses informasi penyuluhan pertanian (Cyber Extension). Hal ini disebabkan karena sumberdaya manusia masih kurang dalam hal pengoperasian komputer/laptop dan keterbatasan kemampuan dalam mengakses internet. Selain itu, keterbatasan sarana dan prasarana dalam hal jaringan internet dan keterbatasan ketersediaan laptop/komputer menjadi penyebab rendahnya kemampuan mereka.

\section{DAFTAR PUSTAKA}

Bahua MI, Jahi A, Asngari PS, Saleh A, Purnaba IGP. 2013. Factors affecting the performance agricultural extension and their impact at behavior maize farmers in Gorontalo Province. Journal of Agricultural Education and Extension. 1: 1-10.

Instruksi Presiden No. 9 Tahun 2000 tentang Pengarusutamaan Gender dalam Pembangunan Nasional.

Mulyandari, RSH., Sumardjo, Lubis, DP.,Nurmala K. 2010. Implementasi Cyber Extension dalam Komunikasi Inovasi Pertanian. Informatika Pertanian Volume 19 (2): 1743.

Okwu, O.J and B.I. Umoru. 2009. A study of women farmers' agricultural information needs and accessibility: A case study of Apa Local Government Area of Benue State, Nigeria. Afr. J.Agric. Res. 4 (12): 14041409.

Permatasari SUD. 2012. Pemanfaatan Teknologi Informasi dan Komunikasi oleh Penyuluh Pertanian (Kasus : Wilayah Dramaga dan Cibinong Kabupaten Bogor). [skripsi]. Bogor (ID): Institut Pertanian Bogor.

Umanailo,BC. 2016. Keterbatasan Penggunaan Teknologi Informasi Pada Pelayanan dan Pembelajatan di Universitas Iqra Buru. Namlea : Universitas Iqra Buru.

Veronice. 2013. Pemanfaatan Teknologi Informasi dan Komunikasi dalam Peningkatan Kompetensi Penyuluh. [Tesis]. Bogor (ID): Sekolah Pascasarjana IPB. 
Wijaya, SA., Sarwprasodjo.S., Febrina. D. 2019. Cyber Extension Penggunaan Media dan Kelancaran Pencarian Informasi di Kalangan Penyuluh Pertanian Kabupaten Bogor. Jurnal Komunikasi Pembangunan. Juli 2019, Volume 17, No. 2.
Wuriani, Zakso A, Suib M. 2014. Kontribusi karakteristik individu dan komitmen profesional terhadap kepuasan kerja dosen prodi keperawatan. [Jurnal]. Pontianak (ID). Universitas Tanjungpura. 